\title{
Preface: All Leaves Fall Back to Their Roots
}

My family history is a history of diaspora. In the short period of the second half of the twentieth century, three generations of my family migrated twice, first from mainland China to Taiwan, and then from Taiwan to the United States. Each generation struggled with its adopted land's sociohistorical context. Every member's personal desires, fortunes, misfortunes, gains, and losses have been inextricably woven into my family's voyage.

My family's migration started with the Chinese Civil War in 1949, when my grandmother had to flee from her home in mainland China. Her son, who was in Chiang Kai-shek's army, brought his mother and his sister across the Taiwan Strait with him to the island of Taiwan. My grandmother was in her late fifties when she fled from Tienlou, her mainland China hometown. Although she lived in Taiwan for four decades, nostalgia for her beloved hometown and the families she left behind haunted her life in Taiwan.

I grew up with her memories of her previous life in Tienlou, memories that she recalled daily in whatever she did. ${ }^{1}$ Although she could not read, she sang many folk poems when her mind was still clear. During my childhood I enjoyed listening to her songs, and I felt the emotion in her voice as she depicted a faraway people and landscape. Even though she sat on the old couch with me as she spun stories of her earlier mainland China experiences, I felt that, in a way, she was not there with me.

As close as I was to my grandmother, I felt that she had never completely 
left her homeland; her body had been transported to Taiwan, but her mind had remained in her beloved China. Throughout the latter half of her life, she always wanted to go back to her mainland home, but she never returned. She passed away at the age of one hundred. Ironically, the Taiwanese restriction on visiting mainland China was lifted the year after her death. My parents and my uncle carried her ashes back to the home she had left behind. There her life came to a close, as a leaf falls back to its roots.

As my mother began her journey back to her childhood home, carrying her mother's ashes, she was eager to embrace her childhood home and to revisit her mainland identity once again. My grandmother's home had also been my mother's home until she was a teenager. My mother was in her mid-fifties when she made the trip back to Tienlou, almost the same age that her mother had been when she left. But, throughout the trip, my mother felt like an outsider. The village relatives that she had expected would warmly greet her instead alienated her. She discovered many changes that she had not anticipated, and she didn't experience the homecoming she had expected at all. After she returned to Taiwan, she shared the rather heartbreaking story of the trip, and I realized how profoundly frustrating the homecoming must have been for her.

Instead of being a joyous return, the trip destroyed the symbolic meaning that the Tienlou house held for my mother. The way the other family members pejoratively hurled the label "Taiwanese" at her hurt her deeply. Bruised by the experience of visiting the mainland, she expressed her frustration, asking "Where on earth is my home? When I am in Taiwan, people identify me as a mainlander. When I go back to my home village in China, people call me Taiwanese. When I visit America, people say I am a foreigner. Where is my home?" Due to frightening childhood memories involving the civil war, my mother was very fearful about living in Taiwan, and she always hoped that one day our family could migrate to the United States. My father, however, had a different view. He once told me, "Where can we go? Taiwan is our home already. We should just appreciate what the land offers and be thankful for the people we encounter every day."

Meanwhile, my older brother and I ended up going in opposite directions. He was deeply engaged in American literature, movies, and jazz, and he now works as an electrical engineer in Silicon Valley's computer industry. Following traditional Chinese values, he believed that as the eldest son in our family he was obligated to study science, because it was the route to so- 
cial status and promised a secure income. After fulfilling his Taiwanese military service, he came to the United States to pursue his Master's degree and Ph.D. He decided to remain in the United States after completing his graduate work to build a career and start a family.

I arrived in the United States to pursue an academic career in 199I. At first I lived in Ithaca, New York, for three years, and then I moved to Berkeley, California. In spite of living so far away, I have stayed closely connected to Taiwanese society and life, reading Internet news from Taiwan daily and commuting between the United States and Taiwan up to three times each year. I receive emails, faxes, and phone calls from my Taiwanese friends and colleagues weekly. Together with my colleagues and friends, I have coordinated projects, initiated political movements, and participated in social activism, even though we were separated by the width of the Pacific Ocean. Somehow, in the midst of leading a transnational life, I have been able to overcome time and space, and to satiate my need to stay connected to the social and cultural networks that I came from. However, instead of celebrating the information age that makes all this possible, I feel I have lost my sense of having a home rooted in a place - the place that fostered my grandmother's nostalgia for half a century; the place my parents imagined could provide our family a secure life; the place my brother saw as a location he could never return to.

The picture in my mind of the place I was once so strongly attached to is now fading away. When I arrived in the United States to pursue a graduate degree at Cornell University in I991, I often missed the mouthwatering Taiwanese xiaochi (snacks) that I had enjoyed when I lived in Taipei. When I returned to Taipei, the first place I headed after getting off the plane was the night market to satisfy my uncontrollable urge for the stir-fried rice noodles, seared oyster pancakes, steamed vegetable dumplings, and fish ball bisque topped with coriander that I had acquired a taste for long ago.

During my nine years of student life in upstate New York and the San Francisco Bay Area, I journeyed back and forth between my American and Taiwan homes as frequently as I could. At first, I viewed every trip back to Taiwan as the quick remedy to alleviate my homesickness. But then something peculiar happened. By 1998 I had been at UC Berkeley for five years and in America for eight. During that year's trip back to Taiwan, I was surprised to find that, for the first time, I felt homesick for Berkeley.

I moved to the Washington, D.C., area in the summer of 2000. One 
rainy afternoon, shortly after settling in D.C., as I was driving and listening to a Joni Mitchell tape, a mixed set of emotions arose (Mitchell 197I). As Joni Mitchell sang "Oh! California, I am coming home," I felt a longing for home. But I did not know where my home was. Was home in Taiwan, in Berkeley, or in D.C.?

As I encountered this ambiguity I wondered if the network of friends and professional colleagues in Taiwan that I was plugged into would always provide me with a way of keeping in touch with the Taiwanese side of myself. As I drove along with Joni Mitchell serenading me, I wondered whether the person that I had become over the years that I had spent in America was still connected to her home and family in Taiwan, and to the memory of her grandmother. Why had my memories of Taiwan and Berkeley been fading away simultaneously? Why had I felt that I was an outsider? How could I have felt alienated in American society after being here for more than a decade?

In the story that I am about to tell, I am not the only outsider. This book shares the story of a group of high-tech Taiwanese engineers who have lived in Silicon Valley for decades. Like me, they are "outsiders" in that they have immigrated to the United States from Taiwan. My brother and his friends are members of this group. Inspired by my brother's migration experience and his reflection on the technological evolution, I decided to take a closer look at how Taiwanese immigrant families who have relocated to Silicon Valley relate their Taiwanese homes in the past to their new American ones. From 1998 to 2004 I conducted fieldwork in Silicon Valley (United States), Hsinchu (Taiwan), and Shanghai and Beijing (China), while I also visited seven high-tech communities outside Silicon Valley. ${ }^{2}$ During this period I interviewed 148 people, including the families of high-tech engineers, hightech production workers, government officials, planning and design professionals, real estate agents, scholars, and researchers. ${ }^{3}$ Based on in-depth interviews, I have tried to come to understand how the high-tech families have made sense of the relationship between their previous home in Taiwan and their current home in Silicon Valley. I have found that their ways of making sense of leaving one home and one culture for another say much about how they think about themselves- how they think about who they are, who they were, and who they are becoming.

I have been confronted by these high-tech families' deep admiration for 
and enjoyment of the American suburban landscape. They also have succeeded in developing a Taiwanese inner-city lifestyle within that suburban landscape. For instance, after my brother had just bought a new house in Fremont, California, he proudly told me that the house was located adjacent to a park and within a five-minute walk of a Ranch 99 Taiwanese shopping center. In that location he can enjoy his suburban detached house while also satisfying his Taiwanese love for urban shopping convenience. More important, his house is also within walking distance of shops that offer good Chinese groceries. My brother's integration of his Taiwanese inner-city identity with his American suburban identity is one example of what I call the transPacific home identity.

In 1998, after six months of conversation with Taiwanese American computer engineers who had relocated to Silicon Valley, I began to realize that many of them actually had two homes, one in California and the other in Hsinchu Science Park in Taiwan. I learned that many of them regularly commuted between their two homes on opposite sides of the Pacific, and that's when I started thinking of them as residents of a trans-Pacific commuter culture. Many of the people I introduce later in this book have homes in both Silicon Valley and Hsinchu Science Park. Others with homes only in Silicon Valley or Hsinchu deeply admire the American suburban landscape while enjoying a California life that re-creates their previous Taiwanese life. I was excited to find that a great number of high-tech engineers and their families had created a unique landscape by taking their California homes and landscapes and transplanting them to Taiwan.

The stories of the trans-Pacific commuters' home identities that I am about to share weave together dream lives, dream careers, and dream houses. This should not, however, be taken as a sign that the lives of these trans-Pacific commuters are perfect or trouble-free. In certain instances the trans-Pacific "dream" has resulted in "nightmare" scenarios, with communities affected by traffic, environmental pollution, and economic segregation. Instead of translating these "dreams" and "nightmares" into theoretical language, I provide a narrative of the commuters' experiences. I prefer to start with the stories that I heard from people whom I studied because these stories enable the reader to become engaged with the storytellers, to find connections with them that relate to the reader's lived experiences. In the approach that I have taken, my theories about my interviewees' lives emerged 
within a process of coming to understand their stories. This approach emphasizes the power of the voices that the author has interviewed, rather than using those voices to prove the author's theories. Within this approach storytelling allows room for theory to emerge and for the reader to better sense how the theory has emerged through an understanding of those whose stories are often untold.

While I use personal narratives and the self-descriptions of engineers' families throughout this book, I also draw on scholarly theoretical and interdisciplinary literatures concerned with landscapes and home identities. These literatures include those of John Horton (sociology), Peggy Levitt (anthropology), Lucy Lippard (art), Clare Cooper Marcus (environmental design), Richard Rorty and Wolfgang Welsch (philosophy), AnnaLee Saxenian (regional economics), Yi-Fu Tuan (human geography), Edward Soja (cultural geography), and Doreen Massey (cultural geography and feminist study). The work of the scholars named above has helped me to develop the concept of a shifting home identity, a concept that is integrated into and generated from my fieldwork interviews. My reflections on Marcus's and Tuan's home identity research added depth to the shifting home identities concept. The concept of "bi-gration," which I explore in chapters 2 and 5, stems from Soja's Thirdspace. Welsch's transculturality profoundly informs my idea of transcultural lifestyles in chapter 5 . Leavitt's research on the transnational family and Lippard's writing about multicentered places influence the way I see Taiwanese families' transnational family lives in chapter 4. In addition, Saxenian's investigation into the travel frequency of Asian immigrant engineers in Silicon Valley provides me the solid data to picture the trans-Pacific activities between Silicon Valley and Taiwan in chapter 3. In addition, Horton's Monterey Park research offers a clear picture of Taiwanese Americans' California dreams between 1980 and early 1990, described here in chapters 5 and 6. Finally, Doreen's feminist view of sense of global space and Rorty's concept of de-essentialized selfhood opened up a new window through which I view the mosaic home landscapes that I describe in chapters 2 and Io.

I see the narrative approach that I take as echoing Rorty, who follows Harold Bloom's understanding that the reader's interpretation of text is as important as the author's intended meaning (Bloom 2000; Rorty 200I). Rorty agrees with Bloom's opinion that "reading" is not about the arguments 
and ideologies that "recontextualize all the books" we previously read (Rorty 200I). To Rorty, "reading" is about the reader's process of understanding how other people (who are different from the reader) think of themselves, construct actions, and create meanings for their lives on their own terms. As Rorty states, "The problem of how to live our own lives then becomes a problem of how to balance our needs against theirs, and their self-descriptions against ours. To have a more educated, developed and sophisticated moral outlook is to be able to grasp more of these needs, and to understand more of these self-descriptions" (ibid.).

In the chapters that follow I attempt to give voice to the untold story of a group of Taiwanese immigrants whose lives inform a newly emerging definition of the relationship between self and place. I had originally thought that immigrants' journeys from Taiwan to Silicon Valley were simply based on a result of their aspirations for a successful life. What I later realized was that their migration stories were as complicated as my grandmother's story. Some of them achieved their dreams and have created a particular way of life for themselves. Others did not. The story I tell in this book is about both their old and new homes and landscapes; it is a story about how their actual or imagined return to their motherland is reflected in the homes they choose to dwell in and the landscapes in which they choose to make their homes. It is a story of how homes and landscapes have enabled an emerging Asian American immigrant population to construct and reconstruct their individual and cultural identities. It is a story of how homes and landscapes express one's departure and return.

In addition to this being a story of departure from homes and landscapes, it is also a story of departure from the traditional lenses through which we see our selves, our homes, and our landscapes. In the process of listening carefully to stories of departure from one's homeland, I began to understand that physical departure engendered a departure from some deeply held conceptions of self and place. My parents' ritual burial of my grandmother's ashes in the landscape in which she was born was their way of enacting a conception of self and place that had been handed down to them through many centuries of Chinese thought, the belief that one's self, one's identity, who one is, is forever tied to one's birthplace.

This traditional concept of self as inextricably wedded to the location of one's birth is captured in the Chinese adage "All leaves fall back to their 
xxii Preface

roots." This adage uses the tree as a metaphor to express the idea that one's identity is always tied to one's place of birth, no matter how far from home one might roam.

The story I tell in this book is about those families who have migrated to California and have constructed for themselves lives that include the experience of commuting back and forth across the Pacific from their new homes to their Taiwanese homeland. In a sense, it is a story of those leaves that the wind has blown far from the tree's roots. Unlike the leaves that fall to the roots, these trans-Pacific commuters fly great distances away from their roots, but their commuting between two homes across vast distances has led them to think in new ways about the relationship between self, home, and landscape. It is a story about how I listened to their stories, and how over time and through many conversations I began to make sense of the home/identity relationship that they had already internalized - a relationship that is less about a return to their roots and more about the fluidity with which they are able to travel from one home to another, from one picture of themselves to another. 